\title{
A comparison of oral midazolam and ketamine with oral midazolam and promethazine in paediatric sedation
}

\section{Porównanie sedacji pediatrycznej przy zastosowaniu podawanych doustnie midazolamu i ketaminy oraz midazolamu i prometazyny}

\author{
Farzad Bozorgi ${ }^{1}$, Iraj Gholikhatir ${ }^{1}$, Seyed Jaber Mousavi², Mahsa Rahiminejad ${ }^{3}$, Abolghasem Lali \\ ${ }^{1}$ Department of Emergency Medicine, Orthopedic Research Center, Mazandaran University of Medical Sciences, Sari, Iran \\ 2Department of Community Medicine, Faculty of Medicine, Mazandaran University of Medical Sciences, Sari, Iran \\ ${ }^{3}$ Babol University of Medical Sciences, Babol, Iran
}

Medical Studies/Studia Medyczne 2021; 37 (1): 33-41 DOI: https://doi.org/10.5114/ms.2021.104998

Key words: ketamine, emergency department, midazolam, promethazine, pediatric sedation.

Słowa kluczowe: ketamina, oddział ratunkowy, midazolam, prometazyna, sedacja pediatryczna.

\begin{abstract}
Introduction: Conscious sedation is frequently employed for the management of pre-cooperative or extremely anxious and painful procedures in emergency department paediatric patients. Many medications have been used to sedate children in the emergency department separately and in combination in an attempt to find an ideal sedation regimen. The oral route for conscious sedation is very easy to administer and has good acceptance. However, it seems that there is a need to find a drug with greater effectiveness and fewer complications.

Aim of the research: To compare of oral midazolam and ketamine with oral midazolam and promethazine in sedating paediatric patients referred to the emergency department.

Material and methods: This study was a double-blinded clinical trial involving 102 children aged between 2 and 10 years, who were referred to Sari Imam Khomeini Hospital. These children did not have any contraindication for receiving sedation and were divided randomly into 2 groups. We gave oral midazolam $(0.5 \mathrm{mg} / \mathrm{kg})$ to all patients. Afterward, oral promethazine $(1 \mathrm{mg} / \mathrm{kg})$ was given to one group and oral ketamine $(5 \mathrm{mg} / \mathrm{kg})$ to the other group, both of which were mixed with fruit juice by a pharmacologist. The level of sedation, the child's reaction during separation from his/her parents and while giving the treatment, and the intensity of the child's crying while taking the drug and during treatment were evaluated using the Ramsay and Houpt scale. Furthermore, pain intensity measured by VAS scale, recovery duration, and possible side effects were documented by the research assistant, who was unaware of the given drugs. The data were analysed with SPSS.v19 software using the $t$-test, $\chi^{2}$ test, Mann-Whitney test, and repeated measures methods.

Results: The mean and standard deviation was $5.73 \pm 2.73$ years (in $2-10$-year-old patients) in the midazolam-ketamine group and $5.59 \pm 2.51$ years (in $2-10$-year-old patients) in the midazolam-promethazine group. All of the physiological parameters in both treatment regimens were within the normal range during the sedation and treatment periods. In general, no statically significant differences were found in the physiological changes of the 2 groups. The Ramsey level of sedation was significantly higher in the midazolam-ketamine group compared to the other group $(p<0.05)$. Drug-induced sedation the irritability of children due to separation from their parents $(p=0.01)$, general reaction of children during surgery and treatment $(p=0.03)$, quality of analgesia measured by VAS $(p<0.001)$, and recovery time $(p=0.023)$ were all significantly better in the midazolam-ketamine group than in the midazolam-promethazine group.

Conclusions: Oral midazolam-ketamine will lead to safe and effective sedation in children, in order to perform medical procedures. Using this mixture in comparison with oral promethazine-midazolam can result in less consciousness, crying, and moving during the treatment; therefore, this will lead to less psychosomatic trauma in children and provides a quieter emergency room situation. The low price and availability of the drug as well as children's and parents' satisfaction because of not using a painful injection are other advantages of using these medications and this application method. Moreover, medical emergency specialists can use this desirable method to provide a less anxious and stressful situation for the patient without making long-term complications for them.
\end{abstract}

\section{Streszczenie}

Wprowadzenie: Sedacja bez wyłączenia świadomości jest często stosowana u pacjentów pediatrycznych na oddziałach ratunkowych $\mathrm{w}$ przypadku ryzyka braku współpracy z lekarzem lub wysokiego poziomu lęku i bólu. W sedacji dzieci przebywających na oddziale ratunkowym stosuje się wiele różnych leków, zarówno odrębnie, jak i w skojarzeniu, choć nie 
ustalono dotąd idealnego schematu sedacji. Prostą i powszechnie akceptowaną metodą uzyskania sedacji bez wyłączenia świadomości jest doustne podawanie leków sedatywnych. Konieczne jest jednak określenie, które leki charakteryzują się wysoka skutecznością przy mniejszej liczbie powikłań.

Cel pracy: Porównanie sedacji z zastosowaniem podawanych doustnie midazolamu i ketaminy z sedacją z zastosowaniem podawanych doustnie midazolamu i prometazyny u pacjentów pediatrycznych kierowanych na oddział ratunkowy.

Materiał i metody: Do badania klinicznego prowadzonego metodą podwójnie ślepej próby włączono 102 dzieci w wieku od 2 do 10 lat skierowanych do szpitala im. Imama Chomeiniego w mieście Sari (Iran). U dzieci nie występowały żadne przeciwwskazania do stosowania środków sedatywnych. Losowo wyodrębniono dwie grupy badane. Wszystkim pacjentom podano doustnie midazolam $(0,5 \mathrm{mg} / \mathrm{kg})$. Następnie pacjentom $\mathrm{z}$ jednej grupy ordynowano doustnie prometazynę $(1 \mathrm{mg} /$ $\mathrm{kg}$ ), a pacjentom z drugiej grupy ketaminę ( $5 \mathrm{mg} / \mathrm{kg}$ ), także doustnie. Oba leki podano po wymieszaniu z sokiem owocowym przez farmakologa. Stopień sedacji, reakcje dzieci podczas rozstania z rodzicami oraz leczenia, a także intensywność płaczu przy przyjmowaniu leku i w trakcie leczenia oceniano w skali Ramsaya i Houpta. Nasilenie bólu mierzone w skali VAS, czas powrotu do zdrowia oraz ewentualne działania niepożądane były rejestrowane przez asystenta, który nie miał informacji dotyczących leków podawanych pacjentom. Dane analizowano za pomocą oprogramowania SPSS.v19 z wykorzystaniem testu $t$-Studenta, testu $\chi^{2}$ i testu Manna-Whitneya oraz metod pomiarów powtarzanych.

Wyniki: Wartość średnia z odchyleniem standardowym wyniosła 5,73 $\pm 2,73$ roku (u 2-10-latków) w grupie osób otrzymujących midazolam z ketaminą oraz 5,59 $\pm 2,51$ roku (u 2-10-latków) w grupie, w której stosowano skojarzenie midazolamprometazyna. Wszystkie parametry fizjologiczne w obu schematach leczenia mieściły się $\mathrm{w}$ prawidłowym zakresie podczas sedacji i leczenia. Nie stwierdzono statystycznie istotnych różnic pod względem zmian fizjologicznych w obu grupach. Stopień sedacji w skali Ramseya był istotnie wyższy w grupie otrzymującej midazolam z ketaminą w porównaniu z drugą badaną grupą $(p<0,05)$. Skuteczność sedacji farmakologicznej, stopień drażliwości dzieci wywołanej rozłąką z rodzicami $(p=0,01)$, ogólne reakcje dzieci podczas wykonywanych zabiegów i leczenia $(p=0,03)$, skuteczność analgezji w skali VAS $(p<0,001)$ oraz czas powrotu do zdrowia $(p=0,023)$ były istotnie bardziej korzystne $\mathbf{w}$ grupie otrzymującej midazolam i ketaminę niż w grupie, w której zastosowano midazolam i prometazynę.

Wnioski: Doustna sedacja midazolamem i ketaminą u pacjentów pediatrycznych jest rozwiązaniem skutecznym i bezpiecznym. W porównaniu z doustnym podaniem midazolamu i prometazyny sedacja z zastosowaniem midazolamu i ketaminy może przynosić korzyści w postaci obniżenia świadomości oraz ograniczenia płaczu i ruchliwości dzieci podczas leczenia. Oznacza to mniejsze ryzyko zaburzeń psychosomatycznych, a także usprawnia pracę na oddziale ratunkowym. Inne korzyści z doustnego stosowania midazolamu i ketaminy obejmują niską cenę i dobrą dostępność tych leków, a także wysoki poziom zadowolenia dzieci i rodziców dzięki wyeliminowaniu bolesnego zastrzyku. Opisany schemat leków polecany jest specjalistom z zakresu medycyny ratunkowej, ponieważ umożliwia obniżenie poziomu niepokoju i stresu u pacjentów bez ryzyka długoterminowych powikłań.

\section{Introduction}

Practical guidelines for sedation and analgesia may vary from place to place. Sedation without anaesthetics can be applied to any intervention that causes pain in the patient [1].

Paediatric sedation differs from adult sedation because of differences in size, weight, age, cardiovascular and respiratory mechanisms, and differences in basal metabolism between children and adults.

Children are usually brought to the emergency room due to painful illnesses and injuries. More painful or unpleasant diagnostic and therapeutic measures may be required during the visit.

The cooperation of the child patient with the physician is the primary precondition for the care, and if the physician cannot properly establish this cooperation in the child, one can certainly not expect success and effective treatment.

Therefore, it is expected to be a safe and effective way to relieve pain to sedate children.

Recent articles have suggested an increasing preference for the use of sedation and general anaesthesia in the treatment of anxious children [2-4].

There are numerous therapeutic strategies, including the use of drugs or non-pharmacological ap- proaches to sedate or change behaviour in paediatric patients [5, 6].

Most methods are based on the use of different medications and methods of administration that provide sedation as one of their main effects. Sedatives can be administered inhalation, orally, rectally, subcutaneously, intramuscularly, or intravenously. The easiest and most acceptable method of drug administration, especially in children, is oral administration [7]. Because it is often well received by patients, the administration is simple and inexpensive, and the risk of adverse events is low due to the slow absorption of the drug [8].

There is a lot of evidence on the use of a variety of medications for sedation by trained physicians in the emergency department. In particular, ketamine has been extensively studied with its simultaneous sedation and soothing [9].

According to a meta-analysis of over 8000 cases, the use of ketamine as the only sedative in children between 2 and 13 years old is safe [10]. Ketamine also shows good sedative effects following oral administration [11]. Of course, ketamine metabolite, i.e. norketamine, can also be used for sedation with minimal side effects. Salivary secretion, hallucinations, and dysfunction in doses greater than $6 \mathrm{mg} / \mathrm{kg}$ orally are more pronounced [11]. 
Permetazine, also known as antihistamine, is a phenothiazine-derived product with anti-vomiting, anti-dizziness, and anti-histamine effects, and it is soothing and analgesic before and after surgery. In oral use, after $20 \mathrm{~min}$, its sedative effects begin, and they persist for $4-6 \mathrm{~h} \mathrm{[12].}$

Midazolam is also a drug that is used alone or in combination with promethazine for sedation in children who require a specific procedure $[4,13,14]$. Among these drugs, benzodiazepines are commonly used as precursors in children [15]. Midazolam is most commonly used in children as benzodiazepine because it has a broad safety margin a soothing dose interval with a toxic dose is high, it does not have active metabolites, and its half-life is short (about $30 \mathrm{~min}$ ), with the time of a procedure It is in harmony. After taking it, it takes 15 to 30 min of sedation while at the same time giving the patient a relatively quick return to normal. It also has an antagonist and has a neutralizing effect [14].

The use of a combination of drugs and a specific prescription method is common to increase efficacy and safety, and to increase patient acceptance. Since the superiority of ketamine is a characteristic of forgetfulness and analgesic, relative cardiovascular stability and its limited effects on the respiratory system [16], and on the other hand, as sedation by benzodiazepines does not produce analgesic effect. By using the combination of ketamine and midazolam, it is possible to initiate more rapid analgesia, more effective forgetfulness, and reduce the dose of ketamine required and reduce the hallucination prevalence [4, 17-19].

The oral combination of midazolam and promethazine is also a safe and effective way to calm children during dental treatments. The combination of these drugs has a greater advantage over their separate use, so that initiation of treatment is quicker and hence is sufficient for emergency medical treatment.

\section{Aim of the research}

Therefore, the aim of this study was to compare the efficacy of midazolam and oral ketamine with midazolam and oral promethazine in paediatric sedation.

\section{Material and methods}

We conducted a randomized, double-blinded, 2-arm, superiority clinical trial.

The work was approved by the local ethics and research committee in Mazandaran University of Medical Sciences, and the procedures were done between 2014.11.22 and 2015.05.21. The samples were children aged 2 to 10 years, with American Society of Anesthesiologists (ASA) classification I or II, who required midazolam for procedural sedation and analgesia for surgical procedures such as laceration repair conducted in the emergency department.
The exclusion criteria were upper airway infection, cardiovascular diseases, head trauma, open eye trauma, CNS disorders, any contraindication for sedation, history of taking sedation or opioids, and ASA class more than 3.

Written informed consent was obtained from the patient's parents or guardians. In addition, an assent was obtained from all children older than 7 years.

The study was registered at the Iranian Registry of Clinical trials (identifier: IRCT20180717040509N2).

The study was conducted at a university-affiliated (educational), tertiary care hospital in a level 1 trauma centre with 92,000 patient visits per year, including approximately 1200 children who receive procedural sedation and analgesia every year.

For initial assessment and weight measurement, standard monitoring including $\mathrm{SpO} 2$ by pulse oximetry, blood pressure by sphygmomanometer, respiratory rate, pulse rate, and temperature was performed. Then simple random allocation was done.

Both groups received oral midazolam $0.5 \mathrm{mg} / \mathrm{kg}$. Then, the patients of group 1 received oral ketamine $5 \mathrm{mg} / \mathrm{kg}$ (57), and group 2 received oral promethazine $(1 \mathrm{mg} / \mathrm{kg})[20,21]$.

Medications were prepared by the clinical pharmacist in the form of 2 syrups containing midazolamketamine and midazolam-promethazine. Syrups were dissolved in $20 \mathrm{ml}$ cranberry to make it tasty. The children drank the syrups in a glass through a straw.

The children were separated from their parents when they were drowsy and confused. If these signs were absent, the separation was made $30 \mathrm{~min}$ after taking the medicine.

For preparation of syrups, $50 \mathrm{mg} / \mathrm{ml}$ ketamine hydrochloride ampoule from Gmbh ROTEXMEDICA, Germany, Midazolam $5 \mathrm{mg} / \mathrm{ml}$ ampoules from chemotherapy company Iran and promethazine syrup $\mathrm{mg} / \mathrm{ml}$ from Tehran Pharmaceutical Company, Iran Chemical Manufacturing Co. were used.

For caution, we provided emergency resuscitation equipment, including anaesthetics and intubation devices, free oxygen, epinephrine, and tube trachea.

Apnoea was defined as SpO2 below 92\% for more than $15 \mathrm{~s}$ or lack of respiratory symptoms based on vision or respiratory sounds in the stethoscope for more than $15 \mathrm{~s}$, except for cases of crying or motion.

The outcomes were measured and recorded by a junior emergency resident who was unaware of the treatment group allocation; PR, BP, RR, and SpO2 were measured every $5 \mathrm{~min}$ and temperature every $15 \mathrm{~min}$.

Sedation severity was measured using the Ramsay Sedation Scale [22].

We used the Houpt grading scale to record the degree of sedation and irritability in children during separation from their parents, the overall behaviour of the child during surgery, and patient crying at the time of taking the drug and at the time of treatment. 


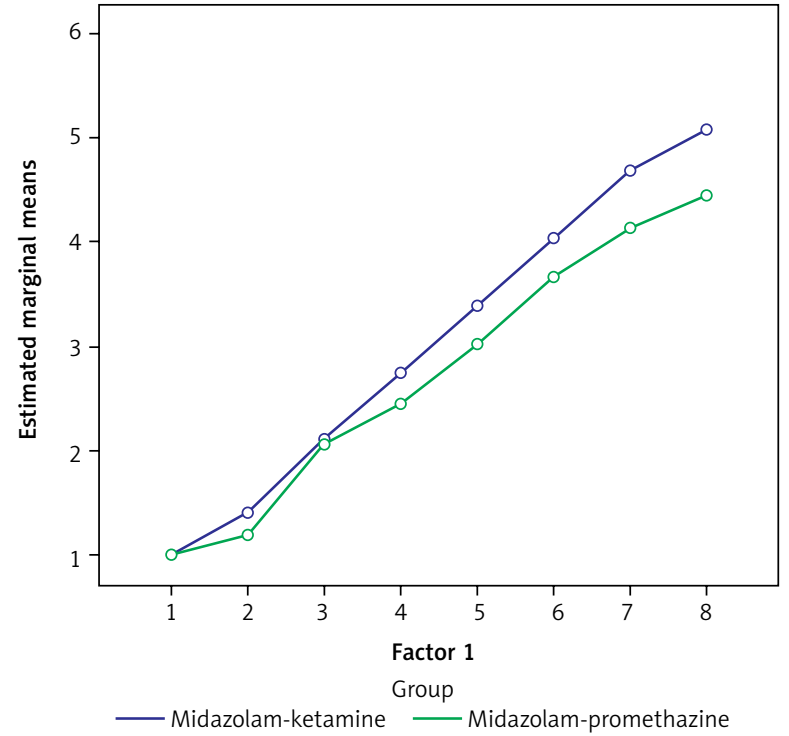

Figure 1. Trend of Ramsey's degree of sedation between the midazolam-ketamine and midazolam-promethazine groups during sedation

Recovery time was classified as short (less than $30 \mathrm{~min}$ ), medium (between 30 to $60 \mathrm{~min}$ ), or long (more than $60 \mathrm{~min}$ ). Analgesia severity was evaluated through the Visual Analogue Scale (painless to worst pain). The presence of nausea and vomiting in patients was also measured by observation and questioning.

After observing the criteria including stable cardiovascular system, open airway, response to stimulations, seating and speech ability, and the presence of the child's guardian, the patient discharged.

We explained to families the discharge instructions after receiving analgesics and sedation in the children.

\section{Statistical analysis}

Raw data were analysed using SPSS software version 19. Data were described in terms of mean \pm standard deviation $( \pm \mathrm{SD}$ ) or frequencies (number of cases) and percentages when appropriate. Comparison of numerical variables between the study groups was done using Student's $t$-test or Mann-Whitney $U$ test for independent samples. For comparing categorical data, the chi-square $\left(\chi^{2}\right)$ test was performed. Fisher's exact test was used instead when the expected frequency was $<5$. $P<0.05$ was considered statistically significant.

\section{Results}

Of the 102 children studied, 49 (48\%) were male and 53 (52\%) were female. Comparison of the 2 groups in terms of gender, using Fisher's exact test, showed no significant difference $(p=1.000)$. The mean age of the studied children (between 2 and 10 years) was $5.73 \pm 2.74$ years in the midazolam-ketamine group and $5.59 \pm 2.53$ years in the midazolam-promethazine group. Comparison of mean age of children in the 2 groups using the $t$-test with independent samples showed no significant difference $(t=0.263, p=0.793)$.

Also, the standard monitoring results of the studied patients were compared including systolic and diastolic blood pressure, respiratory rate, pulse rate, and arterial oxygen saturation in both groups during sedation time, every $5 \mathrm{~min}$ to $40 \mathrm{~min}$, and the temperature of the patients was measured during sedation every $15 \mathrm{~min}$ to $35 \mathrm{~min}$, indicating no significant differences between blood pressure, respiratory rate, arterial oxygen saturation, and temperature in the 2 groups during the follow-up period $(p>0.05)$. However, comparing the pulse rate of the patients under study showed a significant difference between the 2 groups at the $5^{\text {th }} \min (t=2.69, p=0.009)$.

Trends in the degree of Ramsey sedation of children were studied in each of the midazolam-ketamine and midazolam-promethazine groups during sedation. According to Figure 1, the degree of child sedation in both groups has an increasing trend, but comparing the differences between the 2 groups during the follow-up period using analysis of variance with repeated measures indicates a significant difference between the 2 groups ( $p=0.03$ ). The Ramsey sedation rate at every $5 \mathrm{~min}$ of sedation except for 5 and $15 \mathrm{~min}$ in the midazolam-ketamine group showed significantly better sedation than in the midazolampromethazine group.

Degree of sedation and irritability in children during separation from their parents, general behaviour

Table 1. Comparison results between midazolam-ketamine and midazolam-promethazine groups

\begin{tabular}{|c|c|c|c|c|}
\hline Variable & Group & Mean & Standard deviation & $P$-value \\
\hline \multirow{2}{*}{$\begin{array}{l}\text { Degree of sedation and irritability in } \\
\text { children during separation from parents }\end{array}$} & Midazolam-Ketamine & 4.35 & 0.627 & \multirow[t]{2}{*}{0.01} \\
\hline & Midazolam-Promethazine & 3.86 & 0.722 & \\
\hline \multirow{2}{*}{$\begin{array}{l}\text { General behaviour of children during } \\
\text { surgery and labour }\end{array}$} & Midazolam-Ketamine & 4.82 & 0.767 & \multirow[t]{2}{*}{0.03} \\
\hline & Midazolam-Promethazine & 4.35 & 0.716 & \\
\hline \multirow[t]{2}{*}{ The quality of child analgesia in the end } & Midazolam-Ketamine & 1.82 & 0.865 & \multirow[t]{2}{*}{$<0.001$} \\
\hline & Midazolam-Promethazine & 2.61 & 0.874 & \\
\hline
\end{tabular}


Table 2. Comparison of crying severity in the midazolam-ketamine and midazolam-promethazine groups

\begin{tabular}{|c|c|c|c|c|c|c|}
\hline \multirow[t]{2}{*}{ Condition } & \multirow[t]{2}{*}{ Group } & \multicolumn{4}{|c|}{ The intensity of crying based on the Houpt rating scale } & \multirow[t]{2}{*}{$P$-value } \\
\hline & & Hysterical & Consecutive & Fit and very low & No crying & \\
\hline \multirow[t]{2}{*}{ Drug time } & $\begin{array}{l}\text { Midazolam- } \\
\text { Ketamine }\end{array}$ & $\begin{array}{c}11 \\
(21.6 \%)\end{array}$ & $\begin{array}{c}34 \\
(66.7 \%)\end{array}$ & $\begin{array}{c}6 \\
(11.8 \%)\end{array}$ & $\begin{array}{c}0 \\
(0.0 \%)\end{array}$ & \multirow[t]{2}{*}{0.123} \\
\hline & $\begin{array}{l}\text { Midazolam- } \\
\text { Promethazine }\end{array}$ & $\begin{array}{c}20 \\
(39.2 \%)\end{array}$ & $\begin{array}{c}28 \\
(54.9 \%)\end{array}$ & $\begin{array}{c}3 \\
(5.9 \%)\end{array}$ & $\begin{array}{c}0 \\
(0.0 \%)\end{array}$ & \\
\hline \multirow[t]{2}{*}{$\begin{array}{l}\text { Treatment } \\
\text { time }\end{array}$} & $\begin{array}{l}\text { Midazolam- } \\
\text { Ketamine }\end{array}$ & $\begin{array}{c}0 \\
(0.0 \%)\end{array}$ & $\begin{array}{c}0 \\
(0.0 \%)\end{array}$ & $\begin{array}{c}23 \\
(45.1 \%)\end{array}$ & $\begin{array}{c}28 \\
(54.9 \%)\end{array}$ & \multirow[t]{2}{*}{0.175} \\
\hline & $\begin{array}{l}\text { Midazolam- } \\
\text { Promethazine }\end{array}$ & $\begin{array}{c}0 \\
(0.0 \%)\end{array}$ & $\begin{array}{c}2 \\
(3.9 \%)\end{array}$ & $\begin{array}{c}28 \\
(54.9 \%)\end{array}$ & $\begin{array}{c}21 \\
(41.2 \%)\end{array}$ & \\
\hline
\end{tabular}

Table 3. Comparison of recovery time in the 2 groups of midazolam-ketamine and midazolam-promethazine

\begin{tabular}{|lcccc|}
\hline Group & \multicolumn{3}{c}{ Recovery time [min] } & P-value \\
\cline { 2 - 4 } & $\begin{array}{c}\text { Short } \\
\text { (less than 30) }\end{array}$ & $\begin{array}{c}\text { Medium } \\
(30-60)\end{array}$ & $\begin{array}{c}\text { Long } \\
\text { (more than 60) }\end{array}$ & \\
Midazolam-Ketamine & $23(45.1 \%)$ & $28(54.9 \%)$ & $0(0.0 \%)$ & 0.023 \\
Midazolam-Promethazine & $19(37.3 \%)$ & $25(49 \%)$ & $7(13.7 \%)$ & \\
\hline
\end{tabular}

of children during surgery and labour, severity of crying of children when taking medication or treatment, based on Houpt Rating Scale and quality of child analgesia, were evaluated with the VAS criterion and the 2 groups were compared at the end (Tables 1 and 2). The results showed that the mean degrees of sedation and irritability in children during separation from their parents were significantly different between the 2 groups, and the midazolam-ketamine group had a better sedation rate than the midazolam-promethazine group. This result was also found in the general behaviour of children during surgery and labour and was significantly better in the midazolam-ketamine group than in the midazolam-promethazine group. Also, evaluation of the quality of analgesia in children in the 2 groups indicates greater effectiveness of midazolam-ketamine in paediatric sedation compared to midazolam-promethazine.

The results of comparing the severity of crying in the 2 groups at the time of treatment and drug administration showed that there was no significant difference between the midazolam-ketamine and midazolam-promethazine groups at the time of drug use and at the time of treatment.

By comparing the recovery time of the children in the 2 groups, it was found that there was a significant difference between them. Based on the findings in Table 3 , the recovery time of patients in the midazolamketamine group was significantly shorter than that of the midazolam-promethazine group.

In terms of side effects, only 2 cases of nausea and vomiting (3.9\%) were reported in the midazol- am-ketamine group, and there were no specific adverse events in the midazolam-promethazine group $(p=1.000)$.

\section{Discussion}

Intervention with midazolam-ketamine was more successful in behavioural inhibition in children.

In children who underwent surgery, anxiety due to parent separation presents as psychological tension, agitation, slow sleeping, and abnormal behaviours. On the other hand, surgery and anaesthesiology in 2-10-year-olds has a profound impact on their psychological condition in the future. Surgery and anaesthesiology with anxiety can have destructive effects in the future.

In order to perform paediatric surgery or a procedure in an emergency setting, synergy between the surgeon and child is an essential prerequisite. If a physician cannot properly develop this partnership in the child, he/she cannot be expected to succeed and treat the patient appropriately.

In this regard, several therapeutic approaches have been used, including drugs or non-pharmacological methods $[5,6]$.

Although non-pharmacological methods such as audio-visual techniques are effective in reducing children's anxiety, they are not enough, and it is necessary to take medication. Among these precursor drugs, benzodiazepines are commonly used [15].

What is important in prescribing premedication is to ensure that the adequate dosage is obtained to achieve adequate sedation $[3,23]$. 
There is an increasing preference for the use of sedation and general anaesthesia to treat anxiety in very young children. The present clinical trial shows that both protocols are safe.

The positive effect of the drug combination used in this trial was to achieve a favourable sedation using the minimum dose of the drug.

One of the safest and most short-sedation medications for midazolam is Benzodiazepine. This drug is widely used in emergency medical applications [2].

Ketamine is known as an anaesthetic agent and has been used as a sedative for several years [2, 24, 25]. Promethazine is also an antihistamine with a mild sedation effect [26].

In our investigation, all children drank the oral drugs, and only 2 cases (midazolam-ketamine) needed to be fed by syringe.

Due to the fact that emergency procedures usually involve various stimuli that include low to moderate pain stimuli, waiting times should be considered in a way that coincides with the onset of the maximum effect of the drug.

Emergency procedures usually involve various painful stimuli, so a sedative drug should be considered with an onset time (waiting times) that coincides with the peak time.

Shapira's study offered a 30-minute period for separating children in a midazolam-promethazine regimen. riod.

PSC's protocol proposes a 30-minute waiting pe-

If the waiting time is prolonged, the child may have an emotional response, paradoxically. When the child is not sleepy or confused, the waiting time may be too short. On the other hand, in some cases the child may fall asleep within a short period of time after taking the medication, and it is only $45 \mathrm{~min}$ after taking the medication.

Hasty et al. stated that sedation outcomes will be better if painful stimuli such as injection or placement of clamps are scheduled simultaneously with the peak time of the sedative agent [27].

In most relevant studies the waiting time has not been investigated or reported [21, 28, 29]. It is suggested that this issue be considered in future studies.

In the study of Alderson, who used $5 \mathrm{mg} / \mathrm{kg}$ oral ketamine as a premedication, a favourable sedative result was achieved after $20 \mathrm{~min}$ [30]. In our study this time was $30 \mathrm{~min}$ and $35 \mathrm{~min}$ for the midazolamketamine and midazolam-promethazine groups, respectively.

In the use of a sedative, in addition to the sedation properties of the safety aspect of the drug, it is important to evaluate the physiological parameters.

Medication drug safety, investigated by physiologic parameters, is also important, along with sedation properties.
In this study, no patient had SpO2 (arterial oxygen saturation saturation) less than 95\%. For both groups, all physiological parameters including $\mathrm{SpO} 2$ and vital signs were within normal range, and no significant between-group differences were found.

In a study conducted by Gilger et al. in 2004, the use of midazolam and meperidine was associated with more hypoxaemia compared with midazolam and ketamine [31].

There was no case of hypoxaemia during sedation or during the procedure in both groups.

The main advantages of ketamine are amnesia, inducing analgesia, relative cardiovascular stability, and its limited effects on the respiratory system.

Benzodiazepine-induced sedation does not produce analgesia. Using a ketamine - midazolam compound results in faster induction of analgesia, more effective amnesia, less hallucination, and lower dosage of ketamine.

The oral combination of midazolam and promethazine has shown successful and safe sedative results.

The combination of these drugs has a greater advantage over their separate use, so initiation of treatment is quicker and sufficient time for more emergency medical treatment is provided. Using the combination of these drugs, in comparison with their separate use, has many advantages, including faster initiation of treatment and more time to perform emergency procedures.

Shapira's investigation showed that in children who received midazolam-promethazine combination compared with midazolam alone, there is a greater likelihood of a more relaxed or sleepy reaction within $30 \mathrm{~min}$. This is attributed to the combination of midazolam and promethazine [21].

In this study, the 2 groups had a significant difference in terms of Ramsay sedation, overall behaviour of the child during separation from its parents and during the procedure, pain in the VAS scale, and recovery time.

One case of profound sedation was seen in the midazolam-ketamine group.

Several studies have shown the sedative and antianxiety effects of oral ketamine in children before surgery. The results of a study have shown that in paediatric surgeries, the use of oral ketamine within 30 min before surgery and when the child is in the arms of the parents can reduce fear, induce sedation, and increase patient collaboration [32].

Sedative medications are useful for copying anxiety in patients and facilitating treatment for physicians.

In our investigation, a significant percentage of children showed high scores for Houpt and Ramsey scales (indicating greater collaboration). Therefore, it can be said that both drug groups are somewhat effective in soothing children. The effects of midazolam- 
ketamine were significantly better than midazolampromethazine.

Several studies have demonstrated that midazolam has favourable sedation results in terms of acceptable behaviour, ranging from $76.6 \%$ to $100 \%$ of intervention individuals, depending on the used medicinal forms (including oral and intranasal) and doses [33-37].

In our study, in the majority of participating children, especially in the midazolam-ketamine group, were so calm that the treatment was completed satisfactorily.

Kain et al., by examining serum levels of midazolam in children who did not respond to the drug, showed that serum levels of midazolam were similar to those in the group responding appropriately. They believed that the lack of response to medication was due to the pharmacodynamic properties of midazolam (the effect of medicine on the body), not the pharmacokinetics (the effect of the body on the drug, which includes the process of absorption, distribution, and metabolism). They recommend alternative methods, such as changing the type of medication, deep sedation, or general anaesthesia, for these people [38].

According to the findings of this study, children who are less than 4 years old and behave emotionally do not respond to midazolam. These researchers found that the serum level of midazolam was similar in responsive and non-responsive individuals. They believe that the lack of response was due to the pharmacodynamic and not the pharmacokinetic properties of the drug. They suggested alternative methods such as changing the type of medication, deep sedation, or general anaesthesia.

Roelofse et al., in a randomized trial, compared trimeprazine-methadone with oral ketamine-midazolam in the sedation of children aged 2-7 years, for oral surgery. The dose of ketamine in this study was $5 \mathrm{mg} / \mathrm{kg}$ and the midazolam dose was $0.5 \mathrm{mg} / \mathrm{kg}$. They concluded that the combination of oral ketamine and midazolam is a safe, effective, and practical way of controlling children for oral surgery under local anaesthesia [39].

The results of this study are comparable with those of Darlong et al. In the mentioned study, the 2 groups included a low oral dose of midazolam $(0.25 \mathrm{mg} / \mathrm{kg})$ and ketamine ( $3 \mathrm{mg} / \mathrm{kg}$ ), and a high oral dose of midazolam $(0.5 \mathrm{mg} / \mathrm{kg})$ and ketamine $(6 \mathrm{mg} / \mathrm{kg})$. They concluded that a low oral dose of midazolam and ketamine compared to high oral doses would be an effective method for premedication in children undergoing ophthalmic surgery. In that study, none of the children became deeply sedated, and their behaviour during separation from their parents in the low-dose combination group was better than that of the midazolam-alone group [40].
The results of this study can also be compared with those of Jain et al. They compared the use of oral midazolam alone $(0.5 \mathrm{mg} / \mathrm{kg})$ with placebo and a combination of midazolam $(0.25 \mathrm{mg} / \mathrm{kg})$ and ketamine $(1 \mathrm{mg} / \mathrm{kg})$ as premedication for venipuncture for CT scan in paediatric patients. They concluded that a low oral dose of midazolam and ketamine or midazolam alone, both without significant side effects, effectively reduced venipuncture stress. However, the combination of midazolam and ketamine in comparison to midazolam alone puts more children in tranquillity [41].

In the present study, which was conducted on the 2 age-, sex-, and surgical area-matched groups, it was determined that the evaluated responses are similar in girls and boys in terms of prevalence and severity. So, it can be concluded that the incidence of preoperative anxiety reactions has no relation to the child's sex. On the other hand, it has been shown that both ketamine and oral promethazine can be used to relieve children before surgery, but ketamine is more likely to be effective than promethazine. In a way that this drug regimen has been able to reduce the reaction of children during procedure in comparison with oral midazolam-promethazine to a much greater extent and to achieve a mild reaction.

Papineni et al. conducted a systematic review about the side effects of sedation with oral midazolam in paediatric dentistry in 2012. Based on this review, no significant life-threatening side effects were reported in any of the studies. Minor side effects had low frequency, and most of them were nausea and vomiting [42], which was a similar condition to our study.

The incidence of ketamine-induced hallucination is more common in adults than in children and may be reduced by taking benzodiazepines at the same time [43].

Although the side effects of ketamine have been reported rarely in studies involving intravenous or muscular use, it seems that due to the slower absorption of this drug by oral administration, these complications are fewer and this method is safer and less risky [44, 45]. In our study, in the midazolam-ketamine group, only 2 cases of nausea and vomiting (3.9\%) were observed.

The results of Alfonzo-Echeverri's study showed a higher frequency of nausea and vomiting in ketamine use [46].

In our study, as in other similar studies, there was no evidence of aspiration. It is thought that vomiting during the recovery time, during which airway reflexes are intact, is a reason to prevent aspiration [47].

We did not observe any case of rash in the 2 groups. Meanwhile, Karapinar reported a prevalence of $1.1 \%$ in the use of venous midazolam-ketamine combination [16].

\section{Conclusions}

Oral combination of midazolam $(0.5 \mathrm{mg} / \mathrm{kg})$ and ketamine $(5 \mathrm{mg} / \mathrm{kg})$ leads to safe and effective sedation for medical procedures in young children. 
Use of this compound, in comparison with the oral combination of promethazine $(1 \mathrm{mg} / \mathrm{kg})$ and midazolam $(0.5 \mathrm{mg} / \mathrm{kg})$, causes less consciousness, coughing, and movement during treatment. Also, this combination reduces excitement, preoperative anxiety, and fear, which results in positive outcomes for minor emergency procedures and decreased physical and mental harm in children following a more soothing emergency environment.

Other reasons for taking this medication are its low cost, availability, increased satisfaction of the patients and their parents, and non-use of an injectable method that is a painful and distressing.

Also, emergency specialists can easily use this favourable method of sedation without worrying about the increased side effects.

According to these findings, the oral midazolamketamine combination with determined dose may be recommended, $30 \mathrm{~min}$ ago, in paediatric patients undergoing surgical or diagnostic-therapeutic procedures in which short-term analgesia and sedation are required, including dental procedures, bone marrow puncture, spinal cord puncture, needle biopsy, dressing especially in burn wards, catheterization such as dialysis or angiography.

\section{Conflict of interest}

The authors declare no conflict of interest.

\section{References}

1. Jones DR, Salgo P, Meltzer J. Videos in clinical medicine. Conscious sedation for minor procedures in adults. $\mathrm{N}$ Engl J Med 2011; 364: e54.

2. Damle SG, Gandhi M, Laheri V. Comparison of oral ketamine and oral midazolam as sedative agent in pediatric dentistry. J Indian Soc Pedod Prev Dent 2008; 26: 97-101.

3. Hnnallah RS. Pediatric ambulatory anesthesia: role of parents. J Clin Anesth 1995; 7: 597-599.

4. Lökken P, Bakstad OJ, Fonnelöp E, Skogedal N, Hellsten K, Bjerkelund CE, Storhaug K, Oye I. Conscious sedation by rectal administration of midazolam or midazolam plus ketamin as alternatives to general anesthesia for dental treatment of uncooperative children. Scand J Dent Res 1994; 102: 274-280.

5. American Society of Anesthesiologists Task Force on Sedation and Analgesia by Non-Anesthesiologists. Practice guidelines for sedation and analgesia by non-anesthesiologists: a report by the American Society of Anesthesiologists Task Force on sedation and analgesia by nonanesthesiologists. Anesthesiology 2002; 96: 1004-1017.

6. Anderson K. Non pharmacologic methods of analgesia and sedation. Clin Pediatr Emerg Med 2007; 8: 24-28.

7. Alzahrani A, Wyne A. Use of oral midazolam sedation in pediatric dentistry. Pakistan Oral Dental J 2012; 32: 444-455.

8. Kain ZN, Mayes LC, Bell C, Weisman S, Hofstadter MB, Rimar S. Premedication in the United States: a status report. Anesth Anag 1997; 84: 427-432.
9. Atkinson P, Chesters A, Heinz P. Pain management and sedation for children in the emergency department. BMJ 2009; 339: b4234.

10. HowesM. Ketamine for paediatric sedation/analgesia in the emergency department. Emerg Med J 2004; 21: 275-280.

11. Gutstein HB, Johnson KL, Heard MB, Gergory GA. Oral ketamine preanesthetic medication in children. Anesthesiology 1992; 76: 28-33.

12. Malamed S. Sedation. A Guide to Patient Management. $5^{\text {th }}$ ed. Elsevier 2010; 100-109.

13. Babu TA. Prolonged sedation following administration of oral midazolam. Indian Pediatr 2013; 50: 342-343.

14. Folyan MO, Faponie A, Lamikanra A. Seminars on controversial issues. Int J Paediatr Dent 2002; 12: 347-350.

15. Kain ZN, Caldwell-Andrews AA, Krivutza DM, Weinberg ME, Wang SM, Gaal D. Trends in the practice of parental presence during induction of anesthesia and the use of preoperative sedation premedication in the United States, 1995-2000: results of a follow-up national survey. Anesth Analg 2004; 98: 1252-1259.

16. Karapinar B, Yilmaz D, Demirağ K, Kantar M. Sedation with intravenous ketamine and midazolam for painful procedures in children. Pediatr Int 2006; 48: 146-151.

17. Okamoto GU, Duperon DF, Jedrychowski JR. Clinical evaluation of the effects of ketamine sedation on pediatric dental patients. J Clin Pediatr Dent 1992; 16: 253-257.

18. Moscona RA, Ramon I, Ben-David B, Isserles S. A comparison of sedation techniques for outpatient rhinoplasty: midazolam versus midazolam plus ketamine. Plast Reconstr Surg 1995; 96: 1066-1074.

19. Beebe DS, Belani KG, Chang PN, Hesse PS, Schuh JS, Liao JC, Palahniuk RJ. Effectiveness of preoperative sedation with rectal midazolam, ketamine, or their combination in young children. Anesth Analg 1992; 75: 880-884.

20. Dean J. McDonald and Avery Dentistry for the Child and Adolescent. $8^{\text {th }}$ ed. Mosby 2005.

21. Shapira J, Kupietzky A, Kadari A, Fuks AB, Holan G. Comparison of oral midazolam with and without hydroxyzine in the sedation of pediatric dental patients. Pediatr Dent 2004; 26: 492-496.

22. Ramsay MA, Savege TM, Simpson BR, Goodwin R. Controlled sedation with alphaxalone-alphadolone. BMJ 1974; 2: 656-659.

23. Romino SL, Keatley VM, Secrest J, Good K. Parental presence during anesthesia induction in children. AORN J 2005; 81: 780-792.

24. Bal N, Saricaoglu F, Uzun S, Dal D, Celebi N, Celiker V, Aypar U. Perioperative anxiety and postoperative behavioral disturbances in children: comparison between induction techniques. Eur J Anaesthesiol 2006; 23: 470-475.

25. Sullivan DC, Wilson CM, Webb MD. A comparison of two oral ketamine-diazepam regimens for sedation of anxious pediatric dental patients. Pediatr Dent 2001; 23: 233-237.

26. Bui T, Redden RJ, Murphy S. A comparison study between ketamine and ketamine-promethazine combination for oral sedation in pediatric dental patients. Anesth Prog 2002; 49: 8-14.

27. Hasty MF, Vann Jr WJ, Dilley DC, Anderson JA. Conscious sedation of pediatric dental patients: an investigation of chloral hydrate, hydroxyzine pamoate, and meperidine vs. chloral hydrate and hydroxyzine pamoate. Pediatr Dent 1991; 13: 10-19.

28. American Academy on Pediatrics; American Academy on Pediatric Dentistry. Guideline for monitoring and mana- 
gement of pediatric patients during and after sedation for diagnostic and therapeutic procedures. Pediatr Dent 2008-2009; 30: 143-159.

29. Houpt MI, Kupietzky A, Tofsky NS, Koenigsberg SR. Effects of nitrous oxide on diazepam sedation of young children. Pediatr Dent 1996; 18: 236-241.

30. Alderson PJ, Lerman J. Oral premedication for paediatric ambulatory anaesthesia: a comparison of midazolam and ketamine. Can J Anaesth 1994; 41: 221-226.

31. Gilger MA, Spearman RS, Dietrich CL, Spearman G, Wilsey MJ Jr, Zayat MN. Safety and effectiveness of ketamine as a sedative agent for pediatric GI endoscopy. Gastrointest Endosc 2004; 59: 659-663.

32. Hall J, Collyer T. Ketamine sedation in children. Emerg Nurse 2007; 15: 24-27.

33. Al-Zahrani AM, Wyne AH, Sheta SA. Comparison of oral midazolam with a combination of oral midazolam and nitrous oxide-oxygen inhalation in the effectiveness of dental sedation for young children. J Indian Soc Pedod Prev Dent 2009; 27: 9-16.

34. Mortazavi M, Pourhashemi SJ, Khosravi MB, Ashtari S, Ghaderi F. Assessment of a low dose of IV midazolam used orally for conscious sedation in pediatric dentistry. DARU 2009; 17: 79-82.

35. Someri M, Parisinos C, Kharouba J, Cherni N, Smidt A, Aburas Z, Darawshi G, Gaitini L. Optimising the dose of oral midazolam sedation for dental procedures in children: a prospective, randomized, and controlled study. Int J Paediatr Dent 2012; 22: 271-279.

36. Eshghi E, Mazaheri R. The effect of midazolam $0.5 \mathrm{mg} /$ $\mathrm{kg}$ intranasal administration in controlling the behavior of uncooperative children. Dent J Isfahan UMS 2006; 1: 43-48.

37. Wilson KE, Welbury RR, Girdler NM. A study of the effectiveness of oral midazolam sedation for orthodontic extraction of permanent teeth in children: a prospective, randomised, controlled, crossover trial. Br Dental J 2002; 192: 457-462.

38. Kain ZN, MacLaren J, McClain BC, Saadat H, Wang SM, Mayes LC, Anderson GM. Effects of age and emotionality on the effectiveness of midazolam administered preoperatively to children. Anesthesiology 2007; 107: 545-552.

39. Roelofse JA, Louw LR, Roelofse PG. A double blind randomized comparison of oral trimeprazine-methadone and ketamine-midazolam for sedation of pediatric dental patients for oral surgical procedures. Anesth Prog 1998; 45: 3-11.

40. Darlong V, Shende D, Singh M, Garg R, Pandey R, Punj J. Low- versus high-dose combination of midazolam-ketamine for oral premedication in children for ophthalmologic surgeries. Singapore Med J 2011; 52: 506-512.

41. Jain K, Ghai B, Saxena AK, Saini D, Khandelwal N. Efficacy of two oral premedicants: midazolam or a low-dose combination of midazolam-ketamine for reducing stress during intravenous cannulation in children undergoing CT imaging. Paediatr Anaesth 2010; 20: 330-337.

42. Papineni A, Lourenco-Matharu L, Ashley PF. Safety of oral midazolam sedation use in paediatric dentistry: a review. Int J Paediatr Dent 2014; 24: 2-13.

43. White PF, Way WL, Trevor AJ. Ketamine: its pharmacology and therapeutic uses. Anesthesiology 1982; 56: 119-136.

44. Schmid RL, Sandler AN, Katz J. Use and efficacy of lowdose ketamine in the management of acute postoperative pain: a review of current techniques and outcomes. Pain 1999; 82: 111-125.

45. Walder B, Schafer M, Henzi I, Tramer MR. Efficacy and safety of patient controlled analgesia for acute postoperative pain. A quantitative systematic review. Acta Anaesthesiol Scand 2001; 45: 795-804.

46. Alfonzo-Echeverri EC, Berg J, Wild TW, Glass NL. Oral ketamine for pediatric outpatient dental surgery sedation. Pediatr Dent 1993; 15: 182-185.

47. Promethazine. Drug Facts and Comparisons 4.0. Efacts Wolters Kluwer Health; 2010. Available from: http:// www.factsandcomparisons.com/

\section{Address for correspondence:}

\section{Farzad Bozorgi MD}

Department of Emergency Medicine

Orthopedic Research Center

Mazandaran University of Medical Sciences

Sari, Iran

E-mail: Farzadbozorgi1356@gmail.com 